\title{
Evaluation of a Harvester-Baler System Operating in a Rockrose (Cistus laurifolius L.) Shrubland
}

\author{
Raquel Bados, Eduardo Tolosana, Luis Saúl Esteban
}

\begin{abstract}
Biomass collection could contribute to the reduction of wildfire prevention costs by obtaining solid biofuels from shrublands that pose a high fire risk, using mechanical harvesting methods that have not been sufficiently tested in shrub formations. The objective of this study is to evaluate the performance of a harvester-baler system (Biobaler WB55) for collecting rockrose (Cistus laurifolius L.) shrublands biomass, to asses the influence of the cutting rotor tool (blades or hammers) on weight and surface productivities and operating costs, as well as to determine the influence of the standing shrub biomass load on productivity and biomass collection efficiency.

A 31-hour test was conducted on 21 ha of a typical Mediterranean shrubland in the centre of Spain. Data collection included time study, daily collected area, fuel consumption and bale measurements. Samples of fresh biomass from bales were collected for the determination of moisture content. The average collected biomass was $2.3 t_{D M} \cdot h a^{-1}$ (tonnes of dry matter per hectare), with an average productivity of $1.6 t_{D M} \cdot P M H^{-1}$ and an average yield of $0.7 \mathrm{ha} \cdot P M H^{-1}$. Better results were obtained with blades than with hammers in the cutting rotor tool $35 \%$ more collected biomass, $42 \%$ higher weight productivity, $61 \%$ higher collection efficiency and $14 \%$ greater surface productivity). The average harvest-baling costs with blades were estimated at 99.5 $€ \cdot P M H^{-1}, 142.1 € \cdot h a^{-1}$ and $53.9 € \cdot t_{D M}{ }^{-1}\left(34.0 € \cdot t_{W M}{ }^{-1}, €\right.$ per tonne of wet matter $)$, and with hammers $91.5 € \cdot P M H^{-1}, 152.5 € \cdot h a^{-1}$ and $81.4 € \cdot t_{D M}{ }^{-1}\left(51.1 € \cdot t_{W M}{ }^{-1}\right)$.

The analysed harvester-baler was operated without difficulty in this type of vegetation and was able to collect up to 31\% of the shrub biomass load in the study area. The amount of uncollected biomass and the decrease in biomass collection efficiency, as shrub biomass load increases, suggest that possible mechanical improvements are needed to increase biomass collection efficiency.
\end{abstract}

Keywords: forest biomass, wildfire, fuel reduction, clearing, debrushing, baling, cost analysis

\section{Introduction}

Since the middle of the last century, fire recurrence has increased in the Iberian Peninsula and in the overall Mediterranean basin (Mayor et al. 2016, Kovats et al. 2014, Pausas and Fernández-Muñoz 2012). This change in fire regime has been attributed to fuel accumulation following farming land abandonment and extensive natural afforestation combined with extreme drought events (Koutsias et al. 2012, Carvalho et al. 2011, Camia and Amatulli 2009, Hoinka et al. 2009). The gradual abandonment of the agricultural and livestock sectors frequently leads to pastures and croplands covered by shrubs, mainly rockroses (Cistus laurifolius L.) and heathers (Cytisus sp.) (Pérez and Esteban 2008).

According to the EU official Land Use and Cover Area Frame Survey (LUCAS 2012), six Mediterranean countries have over $50 \%$ of the EU28 shrublands (21 Mha), with half of them (10.6 Mha) located in Spain (Mediavilla et al. 2017, Esteban et al. 2018). In this country, more than 100,000 ha $\cdot \mathrm{y}^{-1}$ of wildland have burned over the last decade, with $57 \%$ being shrublands (MAPAMA 2015).

Biomass collection can lessen wildfire risk and contribute to the reduction of costs for wildfire prevention. Integrating clearing and harvesting into a single 

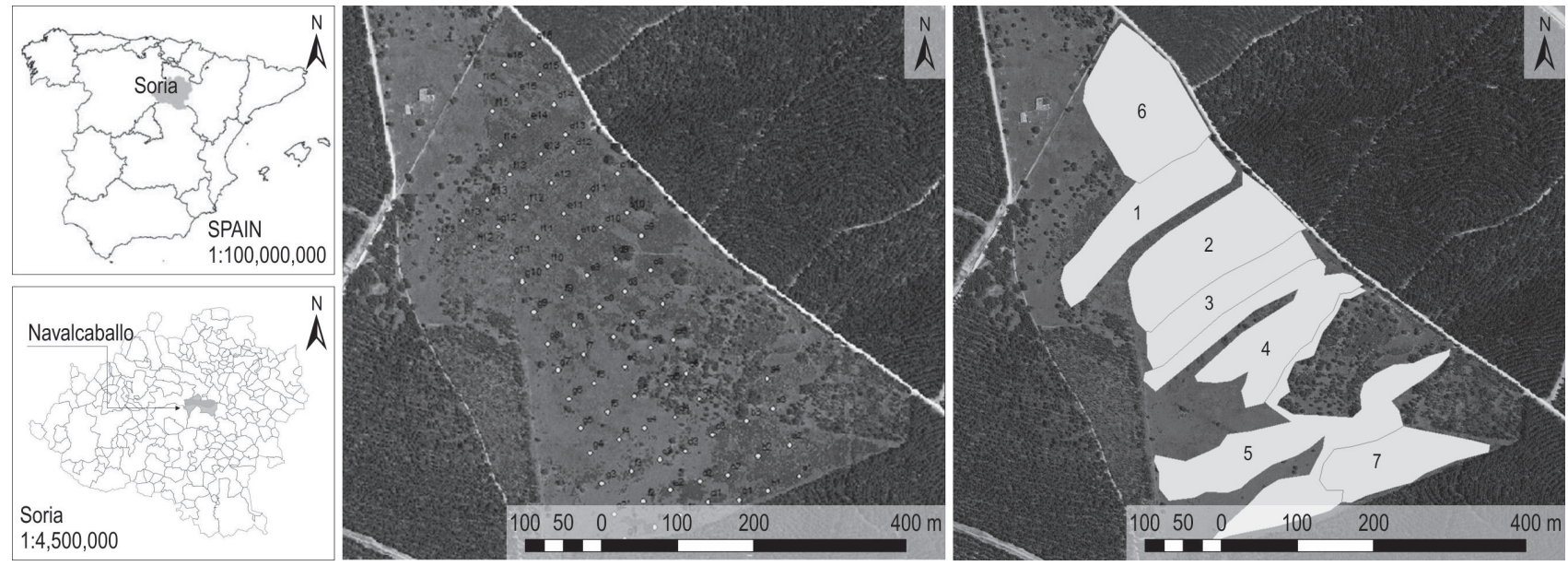

Fig. 1 (a) Location of the study area; (b) Systematic sampling plots location; (c) Daily cleared polygons

machine is an interesting concept that has been developed in some commercial machines and prototypes. Biobaler WB55 is a harvester-baler system that cuts woody vegetation with stems of up to $150 \mathrm{~mm}$ basal diameter and compresses the biomass into round bales $(\varnothing=1.2 \mathrm{~m}$, width=1.2 m). In Canada and the United States, this equipment has been used to clear wild brush, forest understory and encroaching small trees to improve land management in Quebec, Ontario and Minnesota (Savoie et al. 2012), Tennessee (Langholtz et al. 2011), Florida (Do Canto et al. 2011), or to bale woody biomass in a forest application in Georgia, Alabama (Klepac and Rummer 2009) and Saskatchewan (Savoie et al. 2010). Other studies were based on harvesting short-rotation woody crops in plantations in Quebec (Savoie et al. 2013) or Poland (Stolarski et al. 2015). However, the harvester-baler has not been sufficiently tested on Mediterranean shrub formations. In addition, the use of hammers in the harvester-baler cutting rotor has never been evaluated and their use can be an interesting alternative in forest lands, where the terrain is rarely flat and uniform and there are often stones and rocky outcrops that can easily break the blades. The clearings carried out in the study area, two years after finishing the harvest-baling work, led to a reduction of $79 \%$ in fire propagation speed, $73 \%$ in the heat per unit area, $72 \%$ in the intensity of the fire line and up to $82 \%$ in the flame length (González et al. 2017). These figures show the efficiency of clearing a large part of the existing shrub biomass load in wildfire prevention tasks, contributing at the same time to the generation of an alternative source of biofuels.

The objective of this study was to evaluate the performance of the harvester-baler system for collecting rockrose (Cistus laurifolius L.) shrublands biomass, to asses the influence of cutting rotor tool (blades or ham- mers) on collection yields and operating costs, as well as to determine the influence of the standing shrub biomass load on productivity and biomass collection efficiency.

\section{Materials and Methods}

\subsection{Study Area}

The study was conducted on 21.43 ha of abandoned pastureland covered by rockrose (Cistus laurifolius L.) in Navalcaballo, Soria (Spain) (Fig. 1), at an altitude of $1050 \mathrm{~m}$ above sea level. The site has an annual average rainfall of $520 \mathrm{~mm}$ and average annual temperature of $10.5^{\circ} \mathrm{C}$. Site soil classification, according to Soil Taxonomy, corresponds to Inceptisols. Soil conditions were similar in the whole area: gentle slopes, low terrain roughness, no stoniness and a sandy loam texture.

\subsection{Harvester-baler System}

Biomass harvesting and collecting were conducted in the framework of the Life+ Enerbioscrub project. A harvester-baler system (Biobaler WB55) was used for the trial (Fig. 2). This equipment, powered by a $154 \mathrm{~kW}$ tractor (Valtra T194D), includes a harvester unit and a baling unit. As the tractor advances, the harvester unit cuts standing shrubs with 48 teeth (hammers or fixed blades) inserted in a horizontal rotor that strikes the vegetation in an upward motion. Harvested biomass is then propelled to a cylindrical deposit to be compacted in the baling unit.

\subsection{Data Collection}

\subsubsection{Time Study}

The harvest-baling trial was designed to estimate weight productivity $\left(\mathrm{P}, \mathrm{t}_{\mathrm{DM}} \cdot \mathrm{PMH}^{-1}\right)$ and surface 

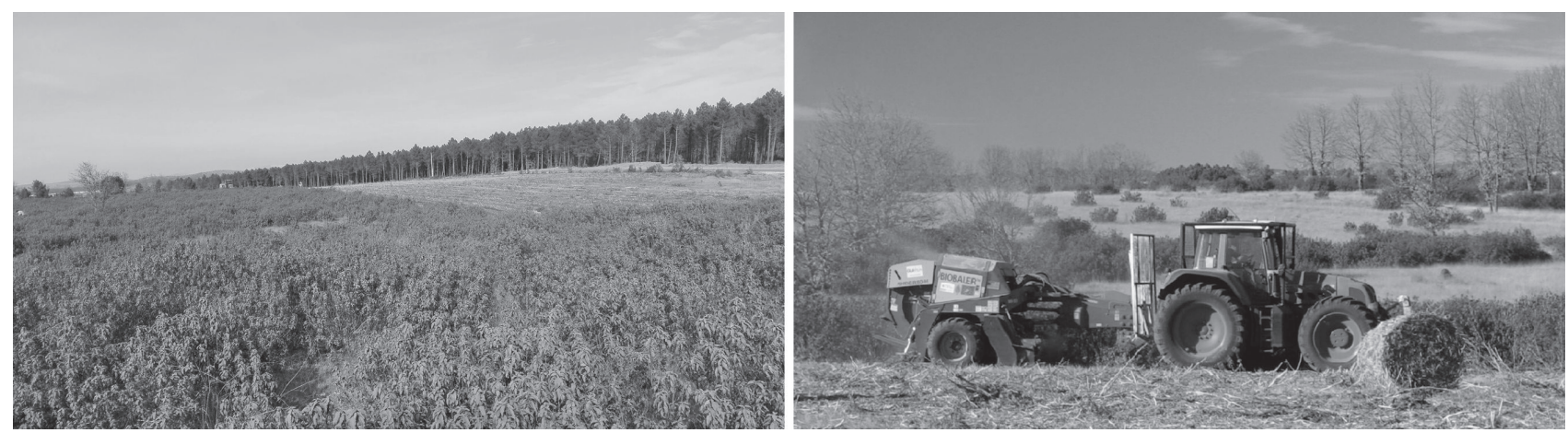

Fig. 2 (a) Rockrose (Cistus laurifolius L.) shrubland partially cleared; (b) Harvester-baler used in the trial
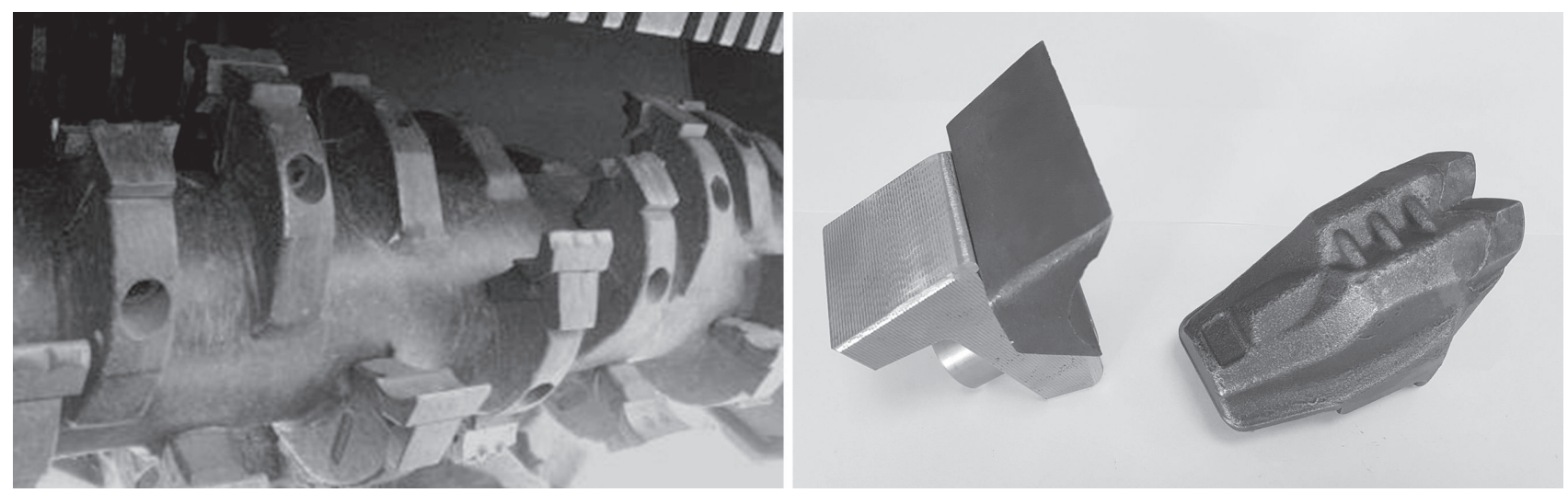

Fig. 3 (a) Harvester cutting rotor provided with blades; (b) Blade (left) and fix hammer (right)

productivity $\left(\mathrm{P}\right.$, ha. $\left.\mathrm{PMH}^{-1}\right)$, costs $\left(€ \cdot \mathrm{t}_{\mathrm{DM}}{ }^{-1}\right)$ and biomass collection efficiency (CE, \%) (ratio between collected and standing shrub biomass) with two different cutting tools in the harvester unit (blades and hammers). The productivity of the harvest-baling process was measured by continuous monitoring of the full individual bale cycle, including harvesting, baling, tying and deposition time, separating productive time from operational delays.

\subsubsection{Distances and Areas}

As replicates, the daily collected area $\left(\right.$ ha $\cdot$ day $\left.^{-1}\right)$ was used. This was delimited and measured using orthophotos (PNOA, 2010) to define daily cleared polygons (Fig. 1). A mobile phone, with GPS and 3G coverage, running the OruxMaps Android app (6.5.0 version) was placed in the tractor cabin. It was configured to record one GPS measurement every ten meters as the tractor moved forward to identify travel distance and time per bale, tractor speed and daily cleared area. The productivity of the harvest-baling process was analysed taking into account the harvester unit cutting tools in each cleared polygon: a) blades or b) fixed hammers with widia (cemented carbide) tips (Fig. 3).

\subsubsection{Bales}

Ten per cent of the bales were weighed in the field with a digital scale ( 1 ton $\pm 0.05 \%$ ) to estimate the average bale weight for each cleared polygon. Fresh collected biomass per cleared polygon was estimated by multiplying the number of bales by the average bale weight. Samples of fresh biomass ( $4 \mathrm{~kg}$ of biomass for each cleared daily polygon) were collected from bales and sent to the Laboratory of Biomass Characterization at CEDER-CIEMAT for the determination of moisture content. The analytical samples were prepared according to UNE standard 14780:2011. The analytical method, drying at $105^{\circ} \mathrm{C}$, was performed following the standard EN 14774-2.

\subsubsection{Shrub Biomass Load}

To determine the collection efficiency of the harvester-baler, a previous systematic sampling was carried out to estimate standing shrub biomass load. 35 georeferenced circular plots $(\phi 4 \mathrm{~m})$ in the study area were sampled to obtain shrub height $(\mathrm{m})$ and shrub crown cover (\%) values. The average values corresponding to the plots located in each daily cleared 


\section{R. Bados et al. Evaluation of a Harvester-Baler System Operating in a Rockrose (Cistus laurifolius L.) Shrubland (191-203)}

Table 1 Basic parameters and assumptions to estimate fixed, variable and operator costs of a $154 \mathrm{~kW}$ tractor and Biobaler WB55, working in a rockrose shrubland in Navalcaballo (Soria)

\begin{tabular}{|c|c|c|c|}
\hline Parameter & Unit & Tractor T194D, 154 kW & Harvester-baler, Biobaler WB55 \\
\hline Purchase price, $\mathrm{P}$ & $€$ & 107,000 & 111,200 \\
\hline Salvage value, $\%$ of $P$ & $\%$ & 10 & 10 \\
\hline Scheduled machine hours, SMH & $\mathrm{SMH}^{\mathrm{S}}$ year $^{-1}$ & 1760 & 1760 \\
\hline Productive machine hours, $\mathrm{PMH}$ & ${\mathrm{PMH} \cdot \mathrm{year}^{-1}}^{-1}$ & 1496 & 1496 \\
\hline Lifespan & $\mathrm{PMH}$ & 12,000 & 12,000 \\
\hline Interest rate & $\%$ & 4.0 & 4.0 \\
\hline Machine taxes and registrations & $€$ & \multicolumn{2}{|c|}{200} \\
\hline Machine insurances & $€$ & \multicolumn{2}{|c|}{2300} \\
\hline Machine transfers & $€$ & \multicolumn{2}{|c|}{5000} \\
\hline Garaging for machines & $€$ & \multicolumn{2}{|c|}{720} \\
\hline Fuel cost, $F$ & $\left.€ \cdot\right|^{-1}$ & 0.80 & - \\
\hline Average fuel consumption & $\mid \cdot h^{-1}$ & 20 & - \\
\hline Lube and oil, $\%$ of $\mathrm{F}$ & $\%$ & 10 & 10 \\
\hline Repair and maintenance (RM) costs, \% of $P$ & $\%$ & 50 & 50 \\
\hline Number of tyres & unit & 4 & 2 \\
\hline Cost per tyre & $€ \cdot$ tyre ${ }^{-1}$ & 3250 & 2000 \\
\hline Estimated tyre set life, $\mathrm{PMH}$ & $\mathrm{h}$ & 3000 & 1000 \\
\hline Tyre cost per set & $€$ & 13,000 & 4000 \\
\hline Blades, unit & $€$ & - & 25 \\
\hline PMH between blade replacement & $\mathrm{h}$ & - & 5 \\
\hline Blade holders, unit & $€$ & - & 70 \\
\hline PMH between blade holder replacement & $\mathrm{h}$ & - & 50 \\
\hline Hammers, unit & $€$ & - & 53 \\
\hline PMH between hammers replacement & $\mathrm{h}$ & - & 100 \\
\hline Thread roll & $€ \cdot$ roll $^{-1}$ & - & 20.50 \\
\hline PMH between thread rolls replacement & $\mathrm{h}$ & - & 4 \\
\hline Number of operators per shift & unit & 1 & - \\
\hline Average net wage, cost/hour & $€ \cdot h^{-1}$ & 12.47 & - \\
\hline Subsistence allowance & $€ \cdot$ year $^{-1}$ & 2750 & - \\
\hline Other operator costs & $€ \cdot$ year $^{-1}$ & 900 & - \\
\hline Annual social charges for operator & $€ \cdot$ year $^{-1}$ & 5180.21 & - \\
\hline Personal protective equipment & $€ \cdot$ year $^{-1}$ & 100 & - \\
\hline Training cost of employees & $€ \cdot$ year $^{-1}$ & 200 & - \\
\hline Phone charges for operator communication & $€ \cdot$ year $^{-1}$ & 360 & - \\
\hline Insurance, employers liability & $€ \cdot$ year $^{-1}$ & 1000 & - \\
\hline Operator transport & $€ \cdot$ year $^{-1}$ & 7260 & - \\
\hline Number of working days per year & day & - & 220 \\
\hline Number of shifts per day & shift & - & 1 \\
\hline Scheduled hours per shift & $\mathrm{h}$ & - & 8 \\
\hline Production, Biobaler with blades & bales $\cdot \mathrm{PMH}^{-1}$ & - & 6.5 \\
\hline Production, Biobaler with hammers & bales $\cdot \mathrm{PMH}^{-1}$ & - & 4.3 \\
\hline Average weight per bale done with blades, dry matter & $t_{D M} \cdot$ bale $^{-1}$ & - & 0.29 \\
\hline Average weight per bale done with hammers, dry matter & $t_{D M} \cdot$ bale $^{-1}$ & - & 0.26 \\
\hline Productivity with blades & $\mathrm{t}_{\mathrm{DM}} \cdot \mathrm{PMH}^{-1}$ & - & 1.85 \\
\hline Productivity with hammers & $\mathrm{t}_{\mathrm{DM}} \cdot \mathrm{PMH}^{-1}$ & - & 1.13 \\
\hline Machine utilisation rate, Biobaler with blades & $\%$ & - & 85 \\
\hline Machine utilisation rate, Biobaler with hammers & $\%$ & - & 82 \\
\hline
\end{tabular}

PMH: Productive machine hour; SMH: Scheduled machine hour; MUR: Machine utilisation rate; Bb: Biobaler with blades; Bh: Biobaler with hammers; $t_{\mathrm{DM}}$ : tonnes of dry matter 
polygon were entered into a rockrose shrubland biomass estimation model (Bados et al. 2017) for assessing the dry shrub biomass weight per hectare $\left(t_{\mathrm{DM}} \cdot \mathrm{ha}^{-1}\right)$ in each daily cleared polygon. Uncollected biomass was estimated by the difference between the standing shrub biomass load, using the mentioned dry weight equations, and the collected dry biomass weight accounted in each cleared polygon. Uncollected biomass included both machine pick up failures and fine material losses, which after being cleared, did not get into the baling unit and fell to the ground.

\subsubsection{Costs Analysis}

Hourly costs were estimated using the machine rate approach described by Ackerman et al. 2014, based on assumptions in Table 1 . This procedure categorised net equipment costs into three classes: fixed, variable and operator costs. Net costs were calculated by combining productive hourly costs with the production rates recorded in the test. The purchase price of the tractor $(154 \mathrm{~kW})$ and the harvester-baler, minus the corresponding tyre costs, were $107,000 €$ and $111,200 €$, respectively, according to the updated acquisition price paid by CEDER-CIEMAT in 2015. The operation lifetime of the tractor and the harvesterbaler were assumed to be $12,000 \mathrm{~h}$. Repair and maintenance costs were estimated at $50 \%$ of the purchase price. The rest of the variable costs (fuel, oil and lubricants, teeth, teeth holders, hammers and baling thread rolls) were based on actual costs recorded during the test. Operator costs were calculated by taking the gross salary paid by CEDER-CIEMAT for a person doing this kind of work $\left(27,130 € \cdot\right.$ year $\left.^{-1}\right)$. Subsistence allowance and operator transport were estimated considering that operators have to work so remotely that they cannot travel home $75 \%$ of the days and need accommodation and full board. Gross costs include net costs (the total cost of operating the machines fixed, variable and operator costs), company overheads and management costs (15\% over net costs) and profit margin $(6 \%$ over the sum of the previous two amounts).

\section{Results}

\subsection{Shrub Biomass Load Estimation}

According to the systematic sampling results (Table 2), the studied area was covered by rockrose (Cistus laurifolius L.) with an average height of $1.09 \mathrm{~m}$ and $56 \%$ crown cover. Dry shrub biomass load before clearing was estimated at $9.6 \mathrm{t}_{\mathrm{DM}} \cdot \mathrm{ha}^{-1}\left(13.17 \mathrm{t}_{\mathrm{WM}} \cdot \mathrm{ha}^{-1}\right)$, with an average moisture content of $37.2 \%$.

\subsection{Harvester-baler Test Results}

Seven daily cleared polygons were registered in the trial (five of which were harvested with blades and two with hammers) (Fig. 1c). Mechanical setbacks prevented the same number of clearing polygons from being made with each cutting element.

A total of $80.4 t_{\mathrm{WM}}$ (tonnes of wet matter), equivalent to $50.5 \mathrm{t}_{\mathrm{DM}}$ (tonnes of dry matter), were collected during 30.7 productive hours in 21.43 ha. The total number of bales was 181 with an average weight of $444 \mathrm{~kg}_{\mathrm{WM}} \cdot$ bale $^{-1}\left(279 \mathrm{~kg}_{\mathrm{DM}} \cdot\right.$ bale $\left.^{-1}\right)$.

The average collected biomass was $2.6 \mathrm{t}_{\mathrm{DM}} \cdot \mathrm{ha}^{-1}$ $\left(4.16 \mathrm{t}_{\mathrm{WM}} \cdot \mathrm{ha}^{-1}\right)$ with blades and $1.7 \mathrm{t}_{\mathrm{DM}} \cdot \mathrm{ha}^{-1}\left(2.66 \mathrm{t}_{\mathrm{WM}} \cdot \mathrm{ha}^{-1}\right)$ with hammers. Collection efficiency was $31 \%$ with blades and $12 \%$ with hammers.

Average productivity was 6.5 bales. $\mathrm{PMH}^{-1}$ with blades and 4.3 bales. $\mathrm{PMH}^{-1}$ with hammers. The harvest-baling cycle averaged $10 \mathrm{~min} 31 \mathrm{~s}$ per bale. Based on average bale mass and moisture content, the average weight productivity obtained was $1.9 \mathrm{t}_{\mathrm{DM}} \cdot \mathrm{PMH}^{-1}$ (3.0 $\left.\mathrm{t}_{\mathrm{WM}} \cdot \mathrm{PMH}^{-1}\right)$ with blades and $1.1 \mathrm{t}_{\mathrm{DM}} \cdot \mathrm{PMH}^{-1}$ $\left(1.7 \mathrm{t}_{\mathrm{WM}} \cdot \mathrm{PMH}^{-1}\right)$ with hammers. Surface productivities were similar with both cutting tools: 0.7 ha. $\mathrm{PMH}^{-1}$ with blades and 0.6 ha. $\mathrm{PMH}^{-1}$ with hammers. Thus, working with blades resulted in 35\% more collected biomass per hectare, $61 \%$ higher collection efficiency, $42 \%$ higher weight productivity and $14 \%$ greater surface productivity than using hammers.

Tables 2 and 3 show the harvest-baling results, with both blades and fixed hammers in the harvester unit, as well as average values weighted by the area of each daily cleared polygon.

During the trial, a constant machine working speed was used by the machine operator $\left(5 \mathrm{~km} \cdot \mathrm{PMH}^{-1}\right)$, fluctuating at the discretion of the tractor operator within a narrow range between 4.5 and $5.4 \mathrm{~km} \cdot \mathrm{PMH}^{-1}$, without having significant influence on productivity and collection efficiency.

Fig. 4 shows the influence of the standing shrub biomass load over the harvester-baler weight productivity, both with blades and hammers in the harvester cutting rotor. Biomass productivity did not rise as the shrub biomass load increased (Fig. 4). With blades, a slight, but not significant reduction in productivity $\left(R^{2}=0.09\right)$ was observed as the standing biomass load increased. No trend line was made with the two available productivity data using hammers.

Fig. 5 shows the influence of the standing shrub biomass load on the biomass collection efficiency, both with blades and hammers in the harvester cutting rotor. A decreasing collection efficiency was observed when shrub biomass load increased, following a logarithmic equation $\left(R^{2}=0.99\right)$. No trend line was made 
R. Bados et al. Evaluation of a Harvester-Baler System Operating in a Rockrose (Cistus laurifolius L.) Shrubland (191-203)

Table 2 Shrub biomass load estimation, collected biomass per hectare and collection efficiency with Biobaler WB55

\begin{tabular}{|c|c|c|c|c|c|c|c|c|c|c|}
\hline Parameter & PN & A & SB & $\mathrm{BN}$ & BWW & $\mathrm{M}$ & BDW & $\mathrm{CB}$ & $\mathrm{BL}$ & CE \\
\hline \multirow{5}{*}{ BLADES } & 1 & 2.53 & 11.2 & 29 & 446 & 37.0 & 281 & 3.2 & 8.0 & 28.8 \\
\hline & 2 & 3.44 & 8.7 & 30 & 446 & 39.3 & 271 & 2.4 & 6.2 & 28.9 \\
\hline & 3 & 1.78 & 13.9 & 13 & 441 & 37.0 & 278 & 2.0 & 11.9 & 14.5 \\
\hline & 4 & 3.29 & 2.7 & 25 & 441 & 39.3 & 268 & 2.1 & 0.6 & 79.4 \\
\hline & 5 & 5.01 & 8.3 & 48 & 483 & 35.8 & 310 & 2.9 & 5.4 & 34.8 \\
\hline Total/Weighted average & - & 16.05 & 8.3 & 145 & 456 & 37.5 & 285 & 2.6 & 5.7 & 31.3 \\
\hline Std. dev. & - & - & 3.4 & - & - & - & - & 0.4 & 3.3 & - \\
\hline N & - & - & 5 & - & - & - & - & 5 & 5 & - \\
\hline \multirow{2}{*}{ HAMMERS } & 6 & 3.43 & 10.9 & 17 & 441 & 35.0 & 287 & 1.4 & 9.5 & 12.6 \\
\hline & 7 & 1.95 & 18.1 & 19 & 350 & 37.0 & 221 & 2.1 & 15.9 & 11.9 \\
\hline Total/Weighted average & - & 5.38 & 13.5 & 36 & 408 & 36.1 & 263 & 1.7 & 11.8 & 12.2 \\
\hline Std. dev. & - & - & 3.4 & - & - & - & - & 0.4 & 3.1 & - \\
\hline N & - & - & 2 & - & - & - & - & 2 & 2 & - \\
\hline \multicolumn{11}{|c|}{ BLADES AND HAMMERS } \\
\hline Total/Weighted average & $1-7$ & 21.43 & 9.6 & 181 & 444 & 37.2 & 279 & 2.3 & 7.3 & 24.3 \\
\hline Std. dev. & - & - & 4.1 & - & - & - & - & 0.6 & 4.2 & - \\
\hline$N$ & - & - & 7 & - & - & - & - & 7 & 7 & - \\
\hline
\end{tabular}

PN: cleared polygon number; $\mathrm{A}$ : area, ha; SB: standing shrub biomass load, $\mathrm{t}_{\mathrm{DM}} \cdot \mathrm{ha}^{-1} ; \mathrm{BN}$ : number of collected bales; $\mathrm{BWW}$ : average wet weight of the collected bales, $\mathrm{kg}_{\mathrm{wm}} \cdot \mathrm{ball}^{-1}$; $\mathrm{M}^{\mathrm{M}}$ : moisture content, \%; BDW: average dry weight of the collected bales, $\mathrm{kg}_{\mathrm{DM}} \cdot \mathrm{bale}^{-1}$; CB: collected biomass, $\mathrm{t}_{\mathrm{DM}}$ 'ha $^{-1}$; BL: biomass losses, $\mathrm{t}_{\mathrm{DM}} \cdot \mathrm{ha}^{-1}$; CE: collection efficiency, \%; $\mathrm{t}_{\mathrm{DM}}$ : tonnes of dry matter; $\mathrm{kg}_{\mathrm{m}}$ : $\mathrm{kg}$ of wet matter; Std. dev: standard deviation; N: number of cleared polygons

Table 3 Productivities of the harvest-baling process with Biobaler WB55

\begin{tabular}{|c|c|c|c|c|c|c|c|}
\hline Parameter & PN & CB & PT & Bales $^{-1}{ }^{-1}$ & WP, $t_{W M} \cdot \mathrm{PMH}^{-1}$ & $\mathrm{WP}, \mathrm{t}_{\mathrm{DM}} \cdot \mathrm{PMH}^{-1}$ & $\mathrm{SP}$, ha.PMH ${ }^{-1}$ \\
\hline \multirow{5}{*}{ BLADES } & 1 & 3.2 & 5.67 & 5.1 & 2.3 & 1.4 & 0.5 \\
\hline & 2 & 2.5 & 4.78 & 6.3 & 2.8 & 1.7 & 0.7 \\
\hline & 3 & 2.0 & 1.87 & 7.0 & 3.1 & 1.9 & 0.9 \\
\hline & 4 & 2.1 & 4.05 & 6.2 & 2.7 & 1.6 & 0.8 \\
\hline & 5 & 2.9 & 5.92 & 8.1 & 3.9 & 2.5 & 0.9 \\
\hline Total/Weighted average & - & 2.6 & 22.30 & 6.5 & 3.0 & 1.9 & 0.7 \\
\hline Std. dev. & - & 0.4 & - & 1.1 & 0.6 & 0.4 & 0.2 \\
\hline N & - & 5 & - & 5 & 5 & 5 & 5 \\
\hline \multirow{2}{*}{ HAMMERS } & 6 & 1.4 & 5.13 & 3.3 & 1.5 & 1.0 & 0.7 \\
\hline & 7 & 2.1 & 3.23 & 5.9 & 2.1 & 1.3 & 0.6 \\
\hline Total/Weighted average & - & 1.7 & 8.36 & 4.3 & 1.7 & 1.1 & 0.6 \\
\hline Std. dev. & - & 0.4 & 1.0 & 1.2 & 0.3 & 0.2 & 0.0 \\
\hline N & - & 2 & & 2 & 2 & 2 & 2 \\
\hline \multicolumn{8}{|c|}{ BLADES AND HAMMERS } \\
\hline Total/Weighted average & $1-7$ & 2.4 & 30.66 & 5.9 & 2.6 & 1.6 & 0.7 \\
\hline Std. dev. & - & 0.6 & - & 1.5 & 0.8 & 0.5 & 0.2 \\
\hline N & - & 7 & - & 7 & 7 & 7 & 7 \\
\hline
\end{tabular}

PN: cleared polygon number; CB: collected biomass, $\mathrm{t}_{\mathrm{DM}} \cdot \mathrm{ha}^{-1}$; PT: productive time, $\mathrm{h}$; WP: weight productivity, $\mathrm{t}_{\mathrm{WM}} \cdot \mathrm{PMH}^{-1}$; $\mathrm{SP}$ : surface productivity, ha·PMH-1; $\mathrm{t}_{\mathrm{WM}}$ : tonnes of wet matter; $\mathrm{t}_{\mathrm{DM}}$ : tonnes of dry matter; Std. dev: standard deviation; N: number of cleared polygon 


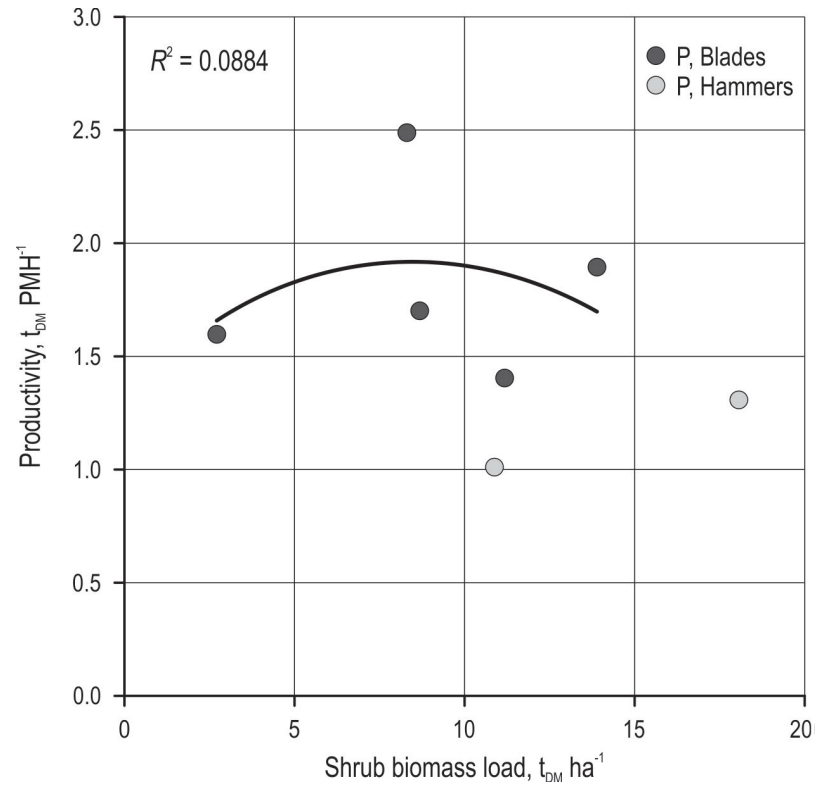

Fig. 4 Influence of standing shrub biomass load $\left(B L, t_{D M} \cdot h^{-1}\right)$ on harvester-baler biomass productivity $\left(\mathrm{P}, \mathrm{t}_{\mathrm{DM}} \cdot \mathrm{PMH}^{-1}\right)$

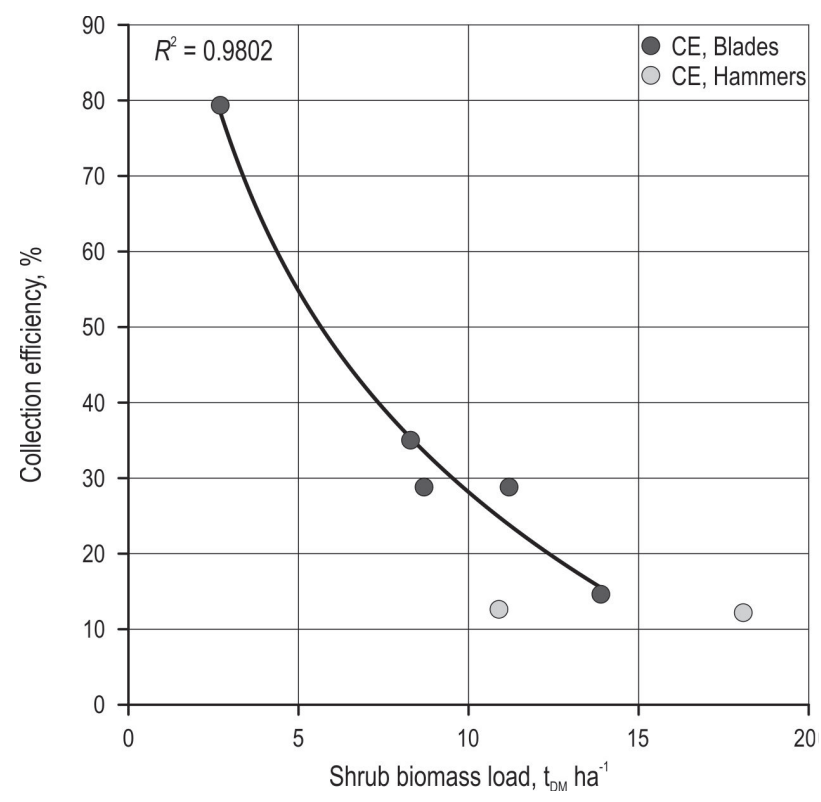

Fig. 5 Influence of standing shrub biomass load $\left(\mathrm{BL}, \mathrm{t}_{\mathrm{DM}} \cdot \mathrm{ha}^{-1}\right)$ on biomass collection efficiency (CE, \%)

with the two available collection efficiency data using hammers, but CE remained constant despite the increase in BL.

\subsection{Operating Costs}

The total net costs of the tractor with the harvesterbaler were estimated at $99.48 € \cdot \mathrm{PMH}^{-1}$ and $53.93 € \cdot \mathrm{t}_{\mathrm{DM}}{ }^{-1}$
(33.98 € $\cdot \mathrm{t}_{\mathrm{WM}}{ }^{-1}$ ) with blades, and $91.52 € \cdot \mathrm{PMH}^{-1}$ and $81.10 € \cdot t_{\mathrm{DM}}{ }^{-1}\left(51.09 € \cdot \mathrm{t}_{\mathrm{WM}}{ }^{-1}\right)$ with hammers, i.e., the net cost per PMH with hammers was $8.0 \%$ lower than with blades but the net cost per $t_{\mathrm{DM}}$ with blades was $50.4 \%$ lower than with hammers. It can be explained by the $42.1 \%$ lower surface productivity obtained with hammers $\left(1.1 \mathrm{t}_{\mathrm{DM}} \cdot \mathrm{PMH}^{-1}\right.$ versus $1.9 \mathrm{t}_{\mathrm{DM}} \cdot \mathrm{PMH}^{-1}$ with blades), with different mean values at a significance level of $87 \%(t=1.8076 ; p$-value $=0.1305)$.

Table 4 Fix, variable and operator costs of a $154 \mathrm{~kW}$ tractor with Biobaler WB55, equipped with blades in the cutting rotor, working in a rockrose shrubland in Navalcaballo (Soria)

\begin{tabular}{|c|c|c|c|}
\hline FIXED COSTS & $€ \cdot$ year $^{-1}$ & $€ \cdot \mathrm{PMH}^{-1}$ & $€ \cdot t_{D M}{ }^{-1}$ \\
\hline Tractor depreciation & $11,581.68$ & 8.03 & 4.33 \\
\hline Biobaler depreciation & $12,036.29$ & 8.34 & 4.50 \\
\hline Tractor interest on AAI & 2585.63 & 1.79 & 0.97 \\
\hline Biobaler interest on AAl & 2687.13 & 1.86 & 1.01 \\
\hline Insurance & 2300 & 1.59 & 0.86 \\
\hline Garaging for machines & 720 & 0.50 & 0.27 \\
\hline Machines tax/registration & 200 & 0.14 & 0.07 \\
\hline Machines transfers & 5000 & 3.34 & 1.87 \\
\hline Total Fixed costs & $37,110.73$ & 25.71 & 13.88 \\
\hline \multicolumn{4}{|c|}{ VARIABLE COSTS } \\
\hline Fuel & $23,091.20$ & 16 & 8.64 \\
\hline Oil and lubricants & 2309.12 & 1.60 & 0.86 \\
\hline Tractor M\&R cost & 6434.27 & 4.46 & 2.41 \\
\hline Biobaler M\&R cost & 6686.83 & 4.63 & 2.50 \\
\hline Tractor tyres & 6253.87 & 4.33 & 2.34 \\
\hline Biobaler tyres & 5968.26 & 4 & 2.23 \\
\hline Blades & 7216 & 5 & 2.70 \\
\hline Blade holders & 2020.48 & 1.40 & 0.76 \\
\hline Thread rolls & 7396.40 & 5.13 & 2.77 \\
\hline Total Variable costs & $67,376.42$ & 46.55 & 25.20 \\
\hline \multicolumn{4}{|c|}{ OPERATOR COSTS } \\
\hline Operator wages & $21,947.20$ & 15.21 & 8.91 \\
\hline $\begin{array}{l}\text { Other operator costs } \\
\text { overtime, compensations }\end{array}$ & 900 & 0.34 & 0.34 \\
\hline Operator benefits and overheads & $16,850.21$ & 11.68 & 6.30 \\
\hline Total Operator Direct Costs & $39,697.41$ & 27.22 & 14.85 \\
\hline $\begin{array}{l}\text { Total Net costs } \\
\text { excluding profit margin }\end{array}$ & $144,184.55$ & 99.48 & 53.93 \\
\hline $\begin{array}{l}\text { Company overheads and } \\
\text { management costs }\end{array}$ & $21,627.68$ & 14.92 & 8.09 \\
\hline Profit margin, before tax & 9948.73 & 6.86 & 3.72 \\
\hline Total Gross costs & $175,760.97$ & 121.27 & 65.74 \\
\hline
\end{tabular}

AAl: Average Annual Investment; M\&R: Maintenance and repairs 
Considering bale productivities of 6.5 bales $\cdot \mathrm{PMH}^{-1}$ with blades and 4.3 bales. $\mathrm{PMH}^{-1}$ with hammers, the net cost amounted to $15.30 € \cdot$ bale $^{-1}$ with blades and $21.28 € \cdot$ bale $^{-1}$ with hammers. Net costs per hectare, according to the surface productivities obtained in the trial $\left(0.7 \mathrm{ha} \cdot \mathrm{PMH}^{-1}\right.$ with blades and $0.6 \mathrm{ha} \cdot \mathrm{PMH}^{-1}$ with hammers), amounted to $142.11 € \cdot \mathrm{ha}^{-1}$ with blades and $152.53 € \cdot$ ha $^{-1}$ with hammers (Tables 4 and 5).

Table 5 Fix, variable and operator costs of a $154 \mathrm{~kW}$ tractor with Biobaler WB55, equipped with hammers in the cutting rotor, working in a rockrose shrubland in Navalcaballo (Soria)

\begin{tabular}{|c|c|c|c|}
\hline FIXED COSTS & $€ \cdot$ year $^{-1}$ & $€ \cdot \mathrm{PMH}^{-1}$ & $€ \cdot t_{D M}^{-1}$ \\
\hline Tractor depreciation & $12,005.40$ & 8.03 & 7.10 \\
\hline Biobaler depreciation & $12,476.64$ & 8.34 & 7.37 \\
\hline Tractor interest on AAI & 2594.11 & 1.73 & 1.53 \\
\hline Biobaler interest on AAI & 2695.93 & 1.80 & 1.59 \\
\hline Insurance & 2300 & 1.54 & 1.36 \\
\hline Garaging for machines & 720 & 0.48 & 0.43 \\
\hline Machines tax/registration & 200 & 0.13 & 0.12 \\
\hline Machines transfers & 5000 & 3.34 & 2.96 \\
\hline Total Fixed costs & $37,992.08$ & 25.40 & 22.46 \\
\hline \multicolumn{4}{|c|}{ VARIABLE COSTS } \\
\hline Fuel & 23,936 & 16 & 14.15 \\
\hline Oil and lubricants & 2393.60 & 1.60 & 1.41 \\
\hline Tractor M\&R cost & 6669.67 & 4.46 & 3.94 \\
\hline Biobaler M\&R cost & 6931.47 & 4.63 & 4.10 \\
\hline Tractor tyres & 6482.67 & 4.33 & 3.83 \\
\hline Biobaler tyres & 6183.68 & 4 & 3.66 \\
\hline Hammers & 792.88 & 0.53 & 0.47 \\
\hline Thread rolls & 6133.60 & 4.10 & 3.63 \\
\hline Total Variable costs & $59,523.56$ & 39.66 & 35.18 \\
\hline \multicolumn{4}{|c|}{ OPERATOR COSTS } \\
\hline Operator wages & $21,947.20$ & 14.67 & 12.97 \\
\hline $\begin{array}{l}\text { Other operator costs } \\
\text { overtime, compensations }\end{array}$ & 900 & 0.53 & 0.53 \\
\hline $\begin{array}{l}\text { Operator benefits and } \\
\text { overheads }\end{array}$ & $16,850.21$ & 11.26 & 9.96 \\
\hline Total Operator Direct Costs & $39,697.41$ & 26.47 & 23.46 \\
\hline $\begin{array}{l}\text { Total Net costs } \\
\text { excluding profit margin }\end{array}$ & $137,213.05$ & 91.52 & 81.10 \\
\hline $\begin{array}{l}\text { Company overheads and } \\
\text { management costs }\end{array}$ & $20,581.96$ & 13.73 & 12.17 \\
\hline Profit margin, before tax & 9467.70 & 6.31 & 5.60 \\
\hline $\begin{array}{l}\text { Total Gross costs } \\
\text { excluding profit margin }\end{array}$ & $167,262.71$ & 111.56 & 98.86 \\
\hline
\end{tabular}

AAl: Average Annual Investment; M\&R: Maintenance and repairs
Table 6 Average costs of rockrose baled biomass at destination $(70 \mathrm{~km})$, expressed in anhydrous material and wet material $(37 \%$ of moisture content)

\begin{tabular}{|l|c|c|c|c|}
\hline \multirow{2}{*}{ Operation } & \multicolumn{3}{|c|}{ Biobaler with blades } & \multicolumn{2}{l|}{ Biobaler with hammers } \\
\cline { 2 - 5 } & $€ \cdot \mathrm{t}_{\mathrm{DM}}{ }^{-1}$ & $€ \cdot \mathrm{t}_{\mathrm{WM}}{ }^{-1}$ & $€ \cdot \mathrm{t}_{\mathrm{DM}}{ }^{-1}$ & $€ \cdot \mathrm{t}_{\mathrm{WM}}{ }^{-1}$ \\
\hline $\begin{array}{l}\text { Harvesting and baling } \\
\text { with Biobaler }\end{array}$ & 53.93 & 33.98 & 81.10 & 51.09 \\
\hline Bale gathering & 10.73 & 6.74 & 10.73 & 6.74 \\
\hline $\begin{array}{l}\text { Loading and transport at } \\
\text { destination, } 70 \mathrm{~km}\end{array}$ & 12.10 & 7.60 & 12.10 & 7.60 \\
\hline Total Net costs & 76.76 & 48.32 & 103.93 & 65.43 \\
\hline $\begin{array}{l}\text { Company overheads and } \\
\text { management costs }\end{array}$ & 11.51 & 7.25 & 15.59 & 9.81 \\
\hline Profit margin, before tax & 5.30 & 3.33 & 7.17 & 4.51 \\
\hline Total Gross costs & 93.57 & 58.90 & 126.69 & 79.76 \\
\hline
\end{tabular}

$t_{D M}$ : tonnes of dry matter; $t_{W M}$ : tonnes of wet matter

The average costs of bale gathering to roadside, bale loading and transport cost to a processing plant were considered to estimate the average cost of rockrose baled biomass at destination. For this purpose, data collected within the framework of the Life+ Enerbioscrub project were used. The unit cost of bale extraction from field to roadside with a bale forwarder was estimated at $10.73 € \cdot t_{\mathrm{DM}}{ }^{-1}$ (Blasco et al. 2018). Loading and transport at an average distance of $70 \mathrm{~km}$, using a trailer with crane, was estimated at $12.1 € \cdot \mathrm{t}_{\mathrm{DM}}{ }^{-1}$ (Esteban et al. 2018). The referred costs did not include general expenses, industrial profits of the companies involved in the logistics chain, biomass owner payments, taxes or possible incomes for shrub clearing services or biomass sales. Table 6 shows the average costs of baled biomass obtained for anhydrous and wet biomass (37\% of moisture content) at destination $(70 \mathrm{~km})$.

\section{Discussion}

According to sampling results, shrub biomass load estimation (9.6 $\left.\mathrm{t}_{\mathrm{DM}} \cdot \mathrm{ha}^{-1}\left(13.17 \mathrm{t}_{\mathrm{WM}} \cdot \mathrm{ha}^{-1}\right)\right)$ was slightly lower than the one offered by TRAGSA (10.9 $\left.\mathrm{t}_{\mathrm{DM}} \cdot \mathrm{ha}^{-1}\right)$ with its own estimation procedure (Blasco et al. 2018). The average shrub height obtained $(1.09 \mathrm{~m})$ was similar to the one estimated by the working group of the National Institute of Agricultural and Food Research and Technology (INIA) for the inventory of existing vegetation in Navalcaballo (Soria). INIA estimated an average shrub height of $1.02 \mathrm{~m}$, average shrub age of 11.2 years and species abundance of Cistus laurifolius L. (80\%) and Rubus spp. (20\%) (González et al. 2018). 
Comparing test results with other rockrose collection trials in Soria (Spain) (Table 7), the collection efficiency with blades (31.3\%) was slightly higher than in Torretartajo (28.5\%) and 35\% higher than in CEDER (20.4\%) (Blasco et al. 2018). Vegetation average age in the tested area was younger than in the other two areas (11 versus 16 and 29 years old, respectively) as well as lower shrub crown cover (55\% versus $60 \%$ and $64 \%$, respectively) (Gonzalez et al. 2018). Both facts can influence the collection efficiency because younger, more flexible and less lignified plants are more easily harvested and baled by Biobaler than older vegetation. On the other hand, collection efficiency tends to decrease when shrub biomass load increases (Fig. 5). It was observed that more lignified plants offered more resistance to being cut, and were easily broken, rooted out and stayed fixed to the ground avoiding to be picked up by the harvester-unit.

Comparing test results with other Mediterranean shrublands (Blasco et al. 2018), the collection efficiency with blades was similar to the value reported with broom (Genista cinerascens) (32.5\%) in Las Navas del Marqués (Ávila), and twice higher than with a mixed shrubland of heather (Erica sp.) and broom (Genista sp.) $(15.0 \%)$ in Figueruela (Zamora). Regarding the results carried out in gorse (Ulex europaeus) shrublands, the trial collection efficiency was within the two reported values in La Coruña (12.4\% in Merlán and $51.0 \%$ in Invied).

On the other hand, the collection efficiency with blades was of the same order as with mixed natural vegetation composed of Serenoa sp. and Ilex sp. in Florida (USA), whose values ranged from $30 \%$ to $22 \%$ (Do Canto et al. 2011), or in shrublands composed of Ilex sp. and Morella sp. in Alabama (USA), where values of $34 \%$ were reported (Klepac and Rummer 2009). However, collection efficiency was lower than in mixed shrublands composed of more flexible and softer wooded plants, like Salix sp. and Populus sp. in Quebec-Ontario and Saskatchewan, with values of $53.5 \%$ and $62.0 \%$, respectively (Savoie et al. 2010 and 2012), and it was three times lower than with Salix plantations, which is easily explained because of the previous land preparation (tillage, ploughing...) in the case of the coppice, compared to the uneven soil conditions in the shrublands or forests, and also because of the more uniform productivity in planted crops (Savoie et al. 2013).

In the test, the collection efficiency with blades was $61 \%$ higher than with hammers ( $31.3 \%$ vs. $12.2 \%$ ). Besides, a better clearing finish was observed with blades than with hammers because part of the plants, especially the youngest and most flexible ones, were hit by the hammers without being cut or were cut at a higher

Table 7 Previous published experiences with Biobaler WB55 using blades as cutting tool

\begin{tabular}{|c|c|c|c|c|c|c|}
\hline Reference & Place & Vegetation & $\begin{array}{c}\text { Surface } \\
\text { productivity } \\
\mathrm{t}_{\mathrm{DM}} \cdot \mathrm{PMH}^{-1}\end{array}$ & $\begin{array}{l}\text { Collected } \\
\text { biomass } \\
t_{D M} \cdot h^{-1}\end{array}$ & $\begin{array}{l}\text { Lost biomass } \\
\qquad t_{D M} \cdot h a^{-1}\end{array}$ & $\begin{array}{c}\text { Collection } \\
\text { efficiency } \\
\%\end{array}$ \\
\hline Savoie et al. 2012 & Quebec, Ontario & Mix (Salix, Populus) & 9.4 & 8.2 & $6.5-9.8$ & 46.5 \\
\hline Savoie et al. 2012 & Minnesot & Mix (Cornus, Rhamnus, Salix) & 8.8 & 3.4 & n.a. & n.a. \\
\hline Langholtz et al. 2011 & Tennessee & Mix & n.a. & 1.9-3.3 & n.a. & n.a. \\
\hline Do Canto et al. 2011 & Florida & Mix (Serenoa, Ilex) & $2.6-4.4$ & 1.3-1.4 & $9.1-10.2$ & $69.8-77.7$ \\
\hline Keplac-Rummer 2009 & Alabama & Mix (llex, Morella) & 6.2 & 4.7 & 12.1 & 66.2 \\
\hline Savoie et al. 2013 & Saskatchewan & Salix (nat. veg.) & $6.7-26.9$ & $2.4-3.9$ & $4.1-17.0$ & 38.0 \\
\hline Savoie et al. 2013 & Quebec & Salix (plantation) & 19.4 & 7.7 & 2.3 & 12.0 \\
\hline Stolarski et al. 2015 & Poland & Salix (plantation) & 18.5 & 4.1 & 1.2 & 6.5 \\
\hline Blasco et al. 2018 & N. del Marqués $(A)$ & $\begin{array}{l}\text { Genista cinerascens (nat. } \\
\text { veg.) }\end{array}$ & 2.1 & 8.5 & 17.7 & 67.5 \\
\hline Blasco et al. 2018 & Figueruela (ZA) & $\begin{array}{l}\text { Mix (Erica, Genista) (nat. } \\
\text { veg.) }\end{array}$ & 1.2 & 1.9 & 10.8 & 85.0 \\
\hline Blasco et al. 2018 & Invied (C) & Ulex europaeus (nat. veg.) & 2.0 & 18.1 & 17.3 & 49.0 \\
\hline Blasco et al. 2018 & Merlán (C) & Ulex europaeus (nat. veg.) & 0.6 & 2.2 & 15.7 & 87.6 \\
\hline Blasco et al. 2018 & CEDER (SO) & Cistus laurifolius (nat. veg.) & 1.9 & 2.8 & 10.9 & 79.6 \\
\hline Blasco et al. 2018 & Navalcaballo (SO) & Cistus laurifolius (nat. veg.) & 1.5 & 2.7 & 8.2 & 75.1 \\
\hline Blasco et al. 2018 & Torretartajo (SO) & Cistus laurifolius (nat. veg.) & 2.0 & 3.2 & 7.9 & 71.5 \\
\hline
\end{tabular}

n.a.: not available; nat. veg.: natural vegetation; A: Ávila (Spain); C: La Coruna (Spain); ZA: Zamora (Spain); SO: Soria (Spain) 
height than with blades. Since the cutting tools support allows blades and hammers to be interchangeable, the option of placing hammers only at the end of the brushcutter could be considered. This way a longer duration of the edge cutting tools, which are usually the most worn, would be achieved with a slight reduction of the collection efficiency.

Collected biomass per hectare $\left(2.4 \mathrm{t}_{\mathrm{DM}} \cdot \mathrm{ha}^{-1}\right)$ was similar to the values provided by TRAGSA S.A. with its own calculation procedure (Blasco et al. 2018) in other rockrose shrublands in Soria $\left(2.8 \mathrm{t}_{\mathrm{DM}} \cdot \mathrm{ha}^{-1}\right.$ in CEDER and $3.2 \mathrm{t}_{\mathrm{DM}} \cdot \mathrm{ha}^{-1}$ in Torretartajo). Similar results were achieved in a gorse (Ulex europaeus) shrubland in Merlán (La Coruña) $\left(2.2 t_{\mathrm{DM}} \cdot \mathrm{ha}^{-1}\right)$ or in a shrubland composed of heather (Erica) and broom (Genista sp.) in Figueruela (Zamora) (1.9 $\left.\mathrm{t}_{\mathrm{DM}} \cdot \mathrm{ha}^{-1}\right)$ using blades as cutting tool. However, collected biomass was lower than in shrublands composed of broom (Genista cinerascens) in Las Navas del Marqués (Ávila) $\left(8.5 \mathrm{t}_{\mathrm{DM}} \cdot \mathrm{ha}^{-1}\right)$ or gorse (Ulex europaeus) in Invied (La Coruña) (18.1 $\left.\mathrm{t}_{\mathrm{DM}} \cdot \mathrm{ha}^{-1}\right)$ using blades in all cases.

The harvester-baler surface productivity when operated in Mediterranean shrublands was lower than in natural stands in North America, probably due to different climate conditions and less xerophile vegetation and lignified shrubs $\left(8.2 \mathrm{t}_{\mathrm{DM}} \cdot \mathrm{ha}^{-1}\right.$ in mixed Salix and Populus shrubland in Quebec and Ontario; $3.4 \mathrm{t}_{\mathrm{DM}} \cdot \mathrm{ha}^{-1}$ in mixed vegetation composed of Cornus, Rhamnus and Salix in Minnesota (Savoie et al. 2012) and $4.7 \mathrm{t}_{\mathrm{DM}} \cdot \mathrm{ha}^{-1}$ in mixed vegetation composed of Ilex and Morella in Alabama (Keplac and Rummer 2009). However, the trial figures were quite close to the results obtained in other tests with mixed natural vegetation: 1.9-3.3 $\mathrm{t}_{\mathrm{DM}} \cdot \mathrm{ha}^{-1}$ in Tennessee (Langholtz et al. 2011); 2.6-4.9 $\mathrm{t}_{\mathrm{DM}} \cdot \mathrm{ha}^{-1}$ in Florida (Do Canto et al., 2011) and 2.4-3.9 $\mathrm{t}_{\mathrm{DM}}$ h $^{-1} \mathrm{~h}^{-1}$ in Saskatchewan (Savoie et al. 2013). Harvester-baler productivity was higher in Salix plantations: $7.7 \mathrm{t}_{\mathrm{DM}} \cdot \mathrm{ha}^{-1}$ in Quebec (Savoie et al. 2013) and $4.1 \mathrm{t}_{\mathrm{DM}} \cdot \mathrm{ha}^{-1}$ in Poland (Stolarski et al. 2015).

Regarding biomass losses, two problems were observed. One of them was a continuous flow of crushed material falling to the ground during the transfer from the harvester unit to the packing chamber. The other one was the obstruction at the edges of the baling unit entrance, especially at the beginning of the day, when vegetation humidity content was higher. The amount of uncollected biomass and the decreasing tendency in biomass collection efficiency when the shrub biomass load increased, suggest that possible mechanical improvements in the harvester-baler are needed to increase biomass collection efficiency and therefore, biomass productivity. Possible improvements to the feeding mechanism of the packing chamber to avoid obstructions could be: the installation of a hydraulic vibrator that facilitates the transit of the biomass; the installation of roller conveyors driven by a hydraulic motor, or the installation of a compressed air system to clean the inlet periodically of material accumulations (Martínez 2018).

Regarding harvest-baling net costs, they were 9\% higher with blades than with hammers $\left(99.48 € \cdot \mathrm{PMH}^{-1}\right.$ vs. $\left.91.52 € \cdot \mathrm{PMH}^{-1}\right)$. However, the lower productivity with hammers $\left(1.7 \mathrm{t}_{\mathrm{DM}} \cdot \mathrm{ha}^{-1}\right.$ vs. $\left.2.6 \mathrm{t}_{\mathrm{DM}} \cdot \mathrm{ha}^{-1}\right)$ made the price of baled biomass $50.3 \%$ higher than with blades $\left(81.10 € \cdot t_{\mathrm{DM}}{ }^{-1}\right.$ vs. $\left.53.93 € \cdot t_{\mathrm{DM}}{ }^{-1}\right)$.

The trial operating costs with blades, including harvest-baling and gathering, $\left(64.66 € \cdot \mathrm{t}_{\mathrm{DM}}{ }^{-1}\right.$ with a productivity of $1.9 \mathrm{t}_{\mathrm{DM}} \cdot \mathrm{PMH}^{-1}$ ), were higher than in other Mediterranean shrubland harvesting experiences within the Life+ Enerbioscrub project (Blasco et al. 2018): $58.94 € \cdot \mathrm{t}_{\mathrm{DM}}^{-1}\left(2.02 \mathrm{t}_{\mathrm{DM}} \cdot \mathrm{PMH}^{-1}\right)$ for rockrose (Cistus laurifolius) in Lubia (Soria); $52.5 € \cdot \mathrm{t}_{\mathrm{DM}}{ }^{-1}\left(2.1 \mathrm{t}_{\mathrm{DM}} \cdot \mathrm{PMH}^{-1}\right)$ for broom (Genista cinerascens) in Ávila and $55.48 € \cdot \mathrm{t}_{\mathrm{DM}}{ }^{-1}$ $\left(1.97 \mathrm{t}_{\mathrm{DM}} \cdot \mathrm{PMH}^{-1}\right)$ for gorse (Ulex europaeus) in La Coruña. However, the trial costs were lower than those for a mixed shrubland of heather (Erica sp.) and broom (Genista florida) collected in Zamora: $82.97 € \cdot \mathrm{t}_{\mathrm{DM}}{ }^{-1}$ $\left(1.22 \mathrm{t}_{\mathrm{DM}} \cdot \mathrm{h}^{-1}\right)$.

The sale of the collected biomass can reduce shrub clearing costs. Considering a sale price of $35 € \cdot t_{\mathrm{WM}}^{-1}$ at destination for baled shrub biomass, similar to the market price for bundled eucalypt biomass, [Rentería, A., Gestamp Biomass (personal communication, 15 January 2019)], shrub clearing gross costs with blades (173.24 € $\cdot \mathrm{ha}^{-1}$ ), including bale gathering and road transport at destination $(70 \mathrm{~km})$, with $4.16 \mathrm{t}_{\mathrm{WM}} \cdot \mathrm{ha}^{-1}$ of collected biomass, could be reduced with the sale of biomass ( $\left.145.60 € \cdot \mathrm{ha}^{-1}\right)$ by $84 \%$.

Given a sale price of $35 € \cdot \mathrm{t}_{\mathrm{WM}}{ }^{-1}$ and a transport distance of $70 \mathrm{~km}$, the collection efficiency needs to increase from $31.3 \%$ to $37.2 \%$, i.e. to $4.95 \mathrm{t}_{\mathrm{WM}} \cdot \mathrm{ha}^{-1}$, for the operation to break even.

According to the TRAGSA forestry rates, which are used as reference in Spain (TRAGSA 2019), the net cost for mechanized brush clearing with a brush cutter (chain, flail or hammer types), in a similar scenario to the trial one (without rocky outcrops and slopes up to $10 \%$ ), ranges between $166.64 € \cdot$ ha $^{-1}$ for areas with crown cover below $50 \%$, and $361.01 € \cdot \mathrm{ha}^{-1}$ for areas with crown cover between $50 \%$ and $80 \%$. The trial clearing cost with blades (142.11 € $\cdot \mathrm{ha}^{-1}$ ) and with hammers $\left(152.53 € \cdot \mathrm{ha}^{-1}\right)$, in a shrubland $56 \%$ crown cover, are $15 \%$ and $8 \%$ lower than TRAGSA rates for areas with crown cover below $50 \%$. A rate of $145.00 € \cdot$ ha $^{-1}$ could be an acceptable rate for mechanized brush 
clearing with the tested harvester-baler in similar scenarios, taking into account the fire suppresion effect, given that both methods have similar effect in wildfire prevention treatment. However, the standing non collected material with the harvester-baler could require a subsequent clearing to optimise livestock use.

The increasing cost of energy carriers and the need of biomass for the biobased industries, enables the use of new resources such as shrub biomass. This is often not collected because of the high operating cost and the low-value of the potential end uses. However, new improvements in mechanical collection machinery, new added values for the products obtained from these marginal lands, and most important, the need for wildfire prevention, make biomass collection and transport a more viable activity.

\section{Conclusions}

A harvester-baler system was operated to harvest a typical Mediterranean shrub formation. The shrub clearing itself was acceptable, but the biomass collection efficiency ( $31 \%$ of the shrub biomass load, using blades as cutting rotor tool in the harvester unit, and $12 \%$ with hammers) could be improved. The average production of collected biomass was $2.6 \mathrm{t}_{\mathrm{DM}} \cdot \mathrm{ha}^{-1}$ with a productivity of $1.4 \mathrm{t}_{\mathrm{DM}} \cdot \mathrm{PMH}^{-1}$ with blades, and $1.7 \mathrm{t}_{\mathrm{DM}} \cdot \mathrm{ha}^{-1}$ with a productivity of $1.1 \mathrm{t}_{\mathrm{DM}} \cdot \mathrm{PMH}^{-1}$ with hammers. Harvested area per hour was similar with both cutting tools $\left(0.7\right.$ ha. $\mathrm{PMH}^{-1}$ with blades and 0.6 ha. $\mathrm{PMH}^{-1}$ with hammers).

The increase in the shrub biomass load did not have a significant influence on biomass productivity. However, decreasing biomass collection efficiency was observed when shrub biomass load increased, following a logarithmic tendency.

The average clearing and harvesting costs were estimated at $99.5 € \cdot \mathrm{PMH}^{-1}, 142.1 € \cdot \mathrm{ha}^{-1}$ and $53.9 € \cdot \mathrm{t}_{\mathrm{DM}}{ }^{-1}$ $\left(34.0 € \cdot \mathrm{t}_{\mathrm{WM}}{ }^{-1}\right)$ with blades, and 91.5€ $€ \cdot \mathrm{PMH}^{-1}, 152.5 € \cdot \mathrm{ha}^{-1}$ and $81.4 € \cdot \mathrm{t}_{\mathrm{DM}}{ }^{-1}\left(51.1 € \cdot \mathrm{t}_{\mathrm{WM}}{ }^{-1}\right)$ with hammers. The analysed harvester-baler can contribute to the reduction of wildfire prevention costs by lessening clearing costs up to $15 \%$ regarding TRAGSA rates in similar scenarios (142.11 € $\cdot$ ha $^{-1}$ vs. $\left.166.64 € \cdot \mathrm{ha}^{-1}\right)$, and $84 \%$ with the sale of shrub biomass for biofuels production.

It would be interesting to evaluate the influence of the machine working speed and the vegetation age and flexibility on biomass productivity and collection efficiency.

A properly planned clearing can be an appropriate environmental management tool to reduce wildfire risk by obtaining sustainable solid biofuels from shrubslands of high flammability risk. It is necessary to use innovative methods of shrub biomass management and collection that are currently not applied in Southern Europe due to the lack of knowledge of technical and economic profitability.

\section{Acknowledgments}

This work was supported by the European LIFE+ Program, through the project "Sustainable management of shrub formations for energy purposes [LIFE13 ENV/ES/000660]«, and coordinated by the CIEMAT (Research Centre for Energy, Environment and Technology). Furthermore, equipment co-funded by the European Regional Development Fund was used: the Biobaler WB55 (project CIEM13-3E-2505) and the tractor (project CIEM15-EE-3378). The authors acknowledge CEDER-CIEMAT and Veolia, S.A. staff for their technical expertise to operate the harvester-baler, the logistical and technical support and the collaboration during the field trials.

\section{Appendix}

Supplementary data related to this article can be found at http:// enerbioscrub.ciemat.es/

\section{References}

Ackerman, P., Belbo, H., Eliasson, L., Jong, A., Lazdins, A., Lyons, J., 2014: The COST model for calculation of forest operations costs. International Journal of Forest Engineering 25(1): 75-81. https://doi.org/10.1080/14942119.2014.903711

Bados, R., Esteban, L.S., Tolosana, E., 2017: Elaboración de modelos de peso de biomasa de jara (Cistus laurifolius L.) en matorrales de la provincia de Soria. Proceedings of the $7^{\text {th }}$ Spanish Forestry Congress, Cáceres (Spain), 7CFE01-115.

Blasco, I., Velasco, H., Calero, R., Carrascosa, A., 2018: Demonstrative trials of harvesting scrub biomass. Techno-Economic Assessment. Project LIFE13 ENV/ES/000660, Deliverable B1 (TRAGSA)

Camia, A., Amatulli, G., 2009: Weather factors and fire danger in the Mediterranean. Earth Observation of Wildland Fires in Mediterranean Ecosystems, 71-82. https://doi. org/10.1007/978-3-642-01754-4_6

Carvalho, A., Monteiro, A., Flannigan, M., Solman, S., Miranda, A.I., Borrego, C., 2011: Forest fires in a changing climate and their impacts on air quality. Atmospheric Environment 45(31): 5545-5553. https://doi.org/10.1016/j. atmosenv.2011.05.010/

Do Canto, J.L., Klepac, J., Rummer, B., Savoie, P., Seixas, F., 2011: Evaluation of two round baling systems for harvesting understory biomass. Biomass and bioenergy 35(5): 21632170. https://doi.org/10.1016/j.biombioe.2011.02.006 
Esteban, L.S., Bados, R., Mediavilla, I., 2018: Gestión sostenible de formaciones arbustivas para uso energético, $57 \mathrm{p}$.

González, B.D., Cañellas, I., González, I., Vázquez, A., Sixto, H., 2017: Manual de evaluación ambiental de los aprovechamientos de matorrales para uso biomásico, $49 \mathrm{p}$.

González, B.D., Sixto, H., Gonzalez, I., Cañellas, I., 2018: Environmental impact assessment of shrub mechanical harvesting for energy purposes. PROJECT LIFE13 ENV/ ES/000660, Deliverable B5-1 (INIA)

Hoinka, K.P., Carvalho, A., Miranda, A.I., 2009: Regionalscale weather patterns and wildland fires in central Portugal. International Journal of Wildland Fire 18(1): 36-49. https:// doi.org/10.1071/WF07045

Koutsias, N., Arianoutsou, M., Kallimanis, A.S., Mallinis, G., Halley, J.M., Dimopoulos, P., 2012: Where did the fires burn in Peloponnisos, Greece the summer of 2007? Evidence for a synergy of fuel and weather. Agricultural and Forest Meteorology 156: 41-53. https://doi.org/10.1016/j. agrformet.2011.12.006/

Klepac, J., Rummer, B., 2009: Evaluation of the WB55 biobaler for baling woody biomass in a forest application. Proceedings of SAF 2009 National Convention [CD-ROM]. Orlando, FL: Society of American foresters. 1-13.

Kovats, R.S., Valentini, R., Bouwer, L.M., Georgopoulou, E., Jacob, D., Martin, E., Rounsevell, M., Soussana, J-F., 2014: Climate change 2014: impacts, adaptation and vulnerability. Part B: regional aspects.

Land Use and Cover Area frame Survey (LUCAS), 2012. Available on line: https://ec.europa.eu/eurostat/web/lucas/ (accessed 3 August 2018)

Langholtz, M., Caffrey, K., Barnett, E., Webb, E., Brummete, M.W., Dowing, M., 2011: Demonstration of the Biobaler harvesting system for collection of small-diameter woody biomass. Oak Ridge National Laboratory.

MAPAMA (Ministerio de Agricultura y Pesca, Alimentación y Medio Ambiente), 2015: Estadísticas de Incendios Forestales en España.

Martínez, D., 2018: Study of feeding of biomass baler Biobaler WB-55. Fuentelsaz, J. and Peña, D. End-of-degree project. University of Zaragoza, Architecture and Engineering School, Mechanical Engineering.
Mayor, A.G., Valdecantos, A., Vallejo, V.R., Keizer, J.J., Bloem, J., Baeza, J., González-Pelayo, O., Machado, A.I., de Ruiter, P.C., 2016: Fire-induced pine woodland to shrubland transitions in Southern Europe may promote shifts in soil fertility. Science of the Total Environment 573: 1232-1241. https://doi.org/10.1016/j.scitotenv.2016.03.243/

Mediavilla, I., Borjabad, E., Fernández, M.J., Ramos, R., Pérez, P., Bados, R., Carrasco, J.E., Estebana, L.S., 2017: Biofuels from broom clearings: Production and combustion in commercial boilers. Energy 141: 1845-1856. https://doi. org/10.1016/j.energy.2017.11.112/

Pausas, J.G., Fernández-Muñoz, S., 2012: Fire regime changes in the Western Mediterranean Basin: from fuel-limited to drought-driven fire regime. Climatic Change 110(-2): 215226. https://doi.org/10.1007/s10584-011-0060-6

Pérez, P., Esteban, L., 2008: Evaluación de diferentes alternativas de recolección del matorral de Cistus laurifolius para la producción de biomasa con fines energéticos. CIEMAT.

Plan Nacional de Ortofotografía Aérea (PNOA) 2010. Available on line: http://pnoa.ign.es/ (accessed 30 January 2019)

Savoie, P., Lavoie, F., D’amours, L., Schroender, W., Kort, J., 2010: Harvesting natural willow rings with a bio-baler around Saskatchewan prairie marshes. Canadian Biosystems Engineering 52(2): 5 p.

Savoie, P., Current, D., Robert, F.S., Hebert, P.L., 2012: Harvest of natural shrubs with a Biobaler in various environments in Quebec, Ontario and Minnesota. Applied Engineering in Agriculture 28(6): 795-801. https://doi. org/10.13031/2013.42473/

Savoie, P., Hébert, P.L., Robert, F.S., Sidders, D., 2013: Harvest of short-rotation woody crops in plantations with a biobaler. Energy and Power Engineering 5(2A): 39-47. https://doi.org/10.4236/epe.2013.52A006/

Stolarski, M.J., Krzyzaniak, M., Szczukowski, S., Tworkowski, J., Grygutis, J., 2015: Changes of willow biomass quality as a renewable energy feedstock harvested with Biobaler. Journal of Elementology 20(3): 717-730. https://doi. org/10.5601/jelem.2014.19.3.769/

TRAGSA Rates, 2019. Available on line: http://www.tragsa. es/es/grupo-tragsa/regimen-juridico/tarifas/ (accessed 15 March 2019) 
Authors' addresses:

Raquel Bados, PhD Student* e-mail: raquel.bados@ciemat.es Prof. Luis Saúl Esteban, PhD e-mail: luis.esteban@ciemat.es CEDER-CIEMAT

Autovía A-15, salida 56

42290 Lubia, Soria

SPAIN

Prof. Eduardo Tolosana, PhD

e-mail: eduardo.tolosana@upm.es

Universidad Politécnica de Madrid

E.T.S.I. Montes, Forestal y del Medio Natural

Campus Ciudad Universitaria

C/ José Antonio Novais 10

28010 Madrid

Received: June 8, 2019

SPAIN

Accepted: September 25, 2019

* Corresponding author 